\title{
Growth-controlling mechanisms on heterotrophic bacteria in the South China Sea shelf: Summer and Winter patterns
}

\author{
Eleanor S. Austria ${ }^{1,2,3}$, Chao-Chen Lai ${ }^{1}$, Chia-Ying Ko ${ }^{4}$, Kuo-Yuan Lee ${ }^{1}$, Hsiang-Yi Kuo $^{1}$, \\ Tzong-Yueh Chen ${ }^{5}$, Jen-Hua Tai ${ }^{1}$, and Fuh-Kwo Shiah ${ }^{1, *}$ \\ ${ }^{1}$ Research Center for Environmental Changes, Academia Sinica, Taipei City, Taiwan \\ ${ }^{2}$ Taiwan International Graduate Program, Academia Sinica and National Central University, Taipei City, Taiwan \\ ${ }^{3}$ Biology Department, Adamson University, Manila, Philippines \\ ${ }^{4}$ Institute of Fishery Sciences, National Taiwan University, Taipei City, Taiwan \\ ${ }^{5}$ Institute of Marine Environment and Ecology, National Taiwan Ocean University, Keelung City, Taiwan
}

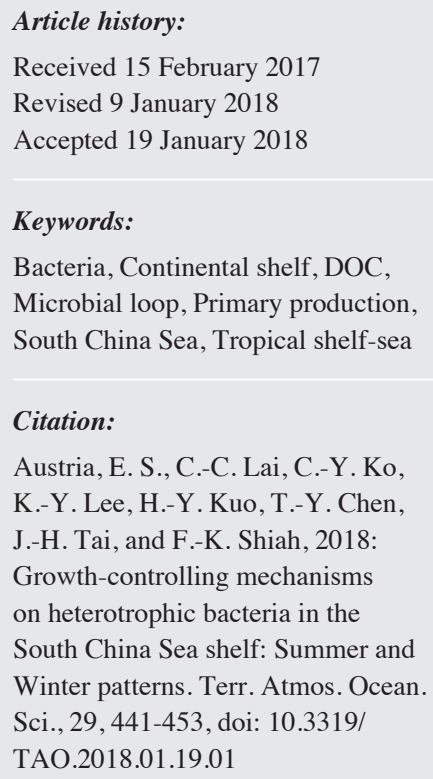

\begin{abstract}
Mechanisms in controlling the growth of heterotrophic bacteria have seldom been explored in the tropical South China Sea (SCS). This study reports the tempospatial distribution patterns and the controlling mechanisms of bacterial biomass $(\mathrm{BB})$, production $(\mathrm{BP})$, and specific growth rate $(\mathrm{B} \mu)$ from one summer (Jun 2010; 4 transects) and two winter (January and December 2011; one transect each) cruises along the northern SCS-shelf. In summer, all three bacterial variables showed strong gradients with greater readings at the inner-shelf then decreasing seaward. The positive correlations of bacterial production rate (BP) and bacterial specific growth rate $(\mathrm{B} \mu)$, with primary production (PP), chlorophyll- $a$, and dissolved organic carbon observed in summer indicate a high possibility of bottom-up (substrate supply) control. Positive bacterial temperature response was observed in the inner to mid-shelf area in winter. There, $\mathrm{B} \mu$ changed proportionally with temperature up to ca. $22^{\circ} \mathrm{C}$. The $\mathrm{Q}_{10}$ (the increase of reaction rate for a temperature rise of $10^{\circ} \mathrm{C}$ ) for $\mathrm{B} \mu$ was $\sim 4.0$, which was in the range reported by coastal studies. Very high BP/PP ratios (summer average: $89 \pm 92 \%$; winter average: $131 \pm 88 \%$ ) indicated bacteria carbon demand relied heavily on allochthonous organic carbon sources such as river input and re-suspension processes, and that the SCS-shelf might be net heterotrophic in these two seasons. In winter, $\mathrm{BP} / \mathrm{PP}$ ratios changed positively with temperature in areas inside the midshelf, suggesting that the coastal zone might become a stronger $\mathrm{CO}_{2}$ source during cold season under a warming climate, if anthropogenic loadings of inorganic nutrients and organic matter remain high in the future.
\end{abstract}

\section{INTRODUCTION}

Although continental shelves constitute $<10 \%$ of the surface area of the ocean (Ryther 1969), they contribute $\sim 20 \%$ of the oceanic primary production and support $\sim 50 \%$ of the fishery production, demonstrating the importance of shelf ecosystems in regulating global ocean carbon-flux (Mantoura et al. 1991; Jickells 1998; Wong et al. 2000). For the last two decades, much attention has been given to temperate shelf seas, including the Middle and South Atlantic Bight, the North Sea, the Mediterranean Sea, and the East

\footnotetext{
* Corresponding author

E-mail:fkshiah@rcec.sinica.edu.tw
}

China Sea (Wong et al. 2015). Still, an accurate estimation of global C-flux in the ocean is quite unlikely to be achieved without information from the shelf systems located at higher and lower latitudes (Borges 2005; Borges et al. 2005).

The northern South China Sea (i.e., SCS) shelf (Fig. 1) is located in tropical region, with the Pearl River (annual freshwater input, $336 \mathrm{~km}^{3} \mathrm{y}^{-1}$; http://www.pearlwater.gov.cn) as the major input of freshwater and terrestrial materials. Aerosol deposition enhanced by monsoons (Lin et al. 2007) also plays a key role in bringing chemicals (e.g., macro nutrients, and trace metals) into this area.

The study of dissolved organic carbon (DOC) is crucially important to our understanding of $\mathrm{C}$-cycling since 
DOC constitutes $>90 \%$ of total organic carbon in aquatic ecosystems (Hedges 1992). In addition to the external inputs (e.g., river discharge, and sediment re-suspension), internal biogenic processes including algal exudation, zooplankton sloppy feeding, viral lyses, particle solubilization, and the release of metabolites, act as the important sources of DOC (Azam 1998). The study of heterotrophic bacterioplankton (abb., bacteria) production is vital because they are the major sink of DOC in aquatic ecosystems (Azam 1998, and citations therein).

$\mathrm{BP}$ is a product of biomass and specific growth rate (i.e., $\mathrm{BP}=\mathrm{BB} \times \mathrm{B} \mu$ ). $\mathrm{BP}$ in the field can be controlled by bottom-up (substrate supply, mainly affects $\mathrm{B} \mu$ ), top-down (protozoan grazing and viral lyses, mainly affects $\mathrm{BB}$ ), and physical (temperature, mainly affects $\mathrm{B} \mu$ ) factors (Ducklow and Shiah 1993; Shiah and Ducklow 1994a, b, 1995). These controlling factors act simultaneously on bacteria, but the weight of each varies seasonally and across ecosystems (Shiah et al. 2003, and citations therein). Phytoplankton PP constitutes the base of aquatic food-webs and is the primary source of autochthonous new organic matter. The cross-system analyses of Cole et al. (1988) proposed that the correlations of BP vs. PP or BP vs. chlorophyll- $a$ in the field could be used as a criterion to assess the relative contribution of bottom-up control. In addition, Cole et al. (1988) pointed out that BP averaged 20 and $30 \%$ of PP on volumetric and areal basis, respectively. This theory has been widely adopted by many field studies in aquatic ecosystems since.

Temperature effects on BP (more specifically, $\mathrm{B} \mu$ ) in the field had not been fully recognized till the study of Bott (1975). However, it is well known that temperature is a physical factor that may affect the metabolic rate of all living organisms. Ducklow and Shiah (1993) proposed that a positive temperature response of $\mathrm{BP}$ (and $\mathrm{B} \mu$ ) could only occur when substrate supply was not limiting. Warmer tempera- ture may provide a better physical environment (lesser activation energy required for biochemical reactions), but bacterial growth cannot occur without proper material supply. This viewpoint was affirmed by subsequent estuarine (Hoch and Kirchman 1993; Shiah and Ducklow 1995; Ducklow et al. 1999; Lomas et al. 2002) and shelf ecosystems studies (see below). Studies in the Chesapeake Bay (Shiah and Ducklow 1994a, b, 1995) indicated that BP and B $\mu$ were low in winter, increasing from spring to summer, and then peaked at $25^{\circ} \mathrm{C}$ (i.e., the $25^{\circ} \mathrm{C}$ growth optima theory).

Previous studies conducted at the East China Sea (i.e., ECS) shelf have indicated that the major controlling factors namely temperature and substrate control processes, on bacterial growth changes with seasons and areas (Shiah et al. 1999, 2000, 2003). The three above-mentioned studies suggested a " $20^{\circ} \mathrm{C}$ threshold theory", which stated that during the cold seasons (winter and spring), bacterial growth in the inner ECS shelf changed positively with temperatures only and maximized at ca. $20^{\circ} \mathrm{C}$; whereas in areas with temperatures $>20^{\circ} \mathrm{C}$ (outer-shelves), bacteria rate parameters (production and specific growth rate) showed positive correlation with PP but not temperature. These studies implied that during the cold season, bacterial growth in the innerand outer-shelf were largely regulated by temperature and substrate supply, respectively. During the warm seasons (summer and autumn), bottom-up control was proposed to be the primary or dominant controlling factor over the ECSshelf due to the strong correlations between bacterial rate parameters and primary production.

The ECS- and SCS-shelf systems are connected but locates in different climate regions. Seawater temperature in any given season in the SCS-shelf should be warmer than that of the ECS-shelf. However, these two systems are subjected to the impacts of many similar external forcing, such as high inorganic nutrients/organic matters loadings from

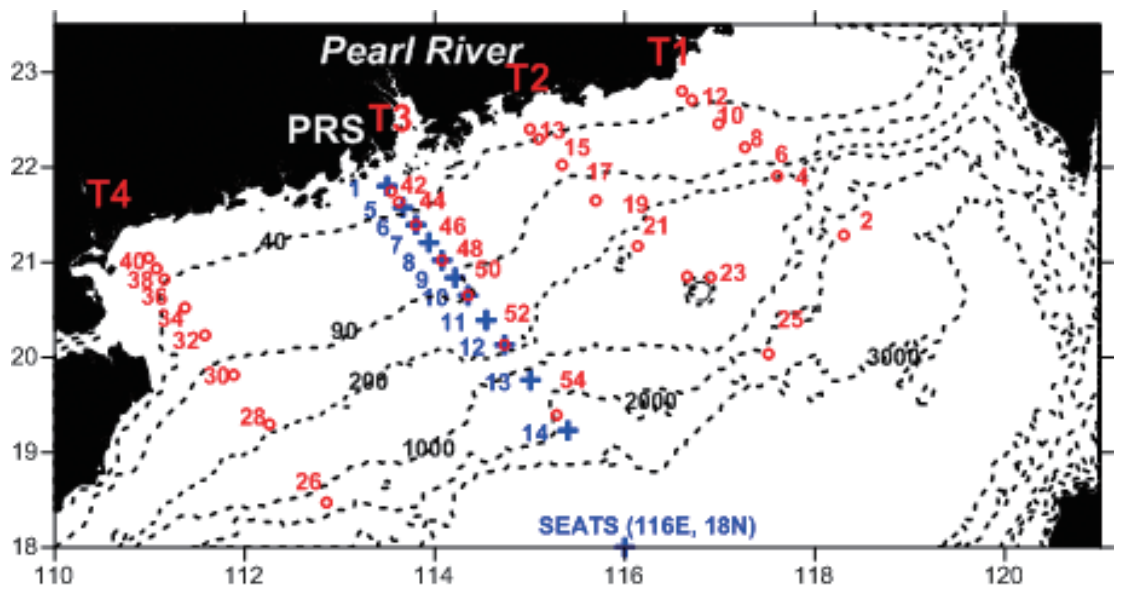

Fig. 1. Map of the South China Sea shelf showing transect number and sampling stations. (a) Summer (T1 - T4) and (b) winter (T4 and PRS) cruises . Open red circles indicate stations of transects T1 - T4. Blue crosses indicate stations of the PRS transect. Dash lines indicate bottom-depth in a unit of meter. 
riverine inputs, high aerosol deposition, seasonal monsoon, etc. We hypothesized that the tempo-spatial patterns of bacteria rate parameters observed in the temperate ECS-shelf could also be seen in the tropical SCS-shelf.

\section{MATERIALS AND METHODS}

\subsection{Study Area and Sampling}

One summer (Jun 2010; transects T1 - T4; Fig. 1) and two winter (January and December 2011) cruises were conducted at the shelf of the SCS. In January 2011, due to bad weather condition, only data of transect 4 were available. Transect from Pearl River mouth to the SEATS (South East Asia Time-series Study) station (i.e., PRS transect; the same as T3 but with different number of stations) were deployed in December 2011. Inner-, mid-, and outer-shelf are defined as the areas with bottom-depths $<50,50-200$, and $>200 \mathrm{~m}$, respectively.

At each station, water samples were taken by $20 \mathrm{~L}$ Go-Flo bottles from six depths from the surface down to $100 \mathrm{~m}$ depth. For stations with bottom-depth shallower than $100 \mathrm{~m}$, the deepest sampling depth was set at the depth $10-15 \mathrm{~m}$ above the bottom. Profiles of temperature, salinity, fluorescence and underwater photosynthetic available radiance (PAR) were recorded by sensors attached to CTD (Conductivity Temperature Density) rosette (General Oceanic Inc. Model 1015). The daily cycle of incident PAR was measured on deck using Biospherical quantum scalar irradiance system (QSP-160) equipped with a surface $2 \pi$ sensor (QSR-240).

\subsection{Concentrations of Inorganic Nutrients and Dissolved Organic Carbon}

Inorganic nutrients were measured following the methods of Parsons et al. (1984). Samples for DOC were filtered through Whatman $\mathrm{GF} / \mathrm{F}$ filter pre-combusted at $550^{\circ} \mathrm{C}$ for one hr. Filtrates were filled into pre-combusted $40 \mathrm{~mL}$ vials. After the addition of several drops of $80 \% \mathrm{H}_{3} \mathrm{PO}_{4}$, vials were sealed with pre-combusted aluminum foil and screw caps with Teflon-coated septa. Before analysis, samples were purged with $\mathrm{CO}_{2}$-free $\mathrm{O}_{2}$ at a flow rate of $350 \mathrm{~mL} \mathrm{~min}^{-1}$ for $>10$ mins. Samples were analyzed by high temperature catalytic oxidation method with a Shimadzu, TOC 5000. All samples were blank $(20-25 \mu \mathrm{M})$ corrected and doublechecked with the deep seawater $(\sim 3000 \mathrm{~m})$ from the South China Sea (DOC 45 - $50 \mu \mathrm{M}$ ) (Hung et al. 2003).

\subsection{Chlorophyll- $a$ and Primary Production}

Chlorophyll- $a$ (Chl- $a$ ) samples were collected on $\mathrm{GF} / \mathrm{F}$, extracted with acetone at $25^{\circ} \mathrm{C}$ overnight and the fluorescence was quantified using a Turner Design 10-AU-005 fluorometer (Parsons et al. 1984). PP was measured by the
${ }^{14} \mathrm{C}$ assimilation method using on deck incubations (Gong et al. 2000). In brief, twenty $250 \mathrm{~mL}$ PC bottles were wrapped with LEE neutral density filters to simulate 9 light levels $(0$, $66,132,264,506,968,1386,2000$, and $2200 \mu \mathrm{E} \mathrm{m}^{-2} \mathrm{~s}^{-1}$ of PAR) with duplicate for each light level. After the inoculation with $\mathrm{H}^{14} \mathrm{CO}_{3}$ - (final conc., $10 \mu \mathrm{Ci} \mathrm{ml}^{-1}$ ), the bottles were incubated for 20 (for coastal sample) or 60 (for open ocean sample) minutes in a self-designed tank with an artificial light source $\left(\sim 2200 \mu \mathrm{E} \mathrm{m}^{-2} \mathrm{~s}^{-1}\right)$. Short incubation time minimizes the possibility of phytoplankton respiration and nitrifying bacteria dark $\mathrm{CO}_{2}$ fixation, which makes our PP data more close to gross production (Shiah et al. 1995, and citations therein). For temperature treatment, the tank was filled with flowing surface seawater. Temperature within tank varied $<2{ }^{\circ} \mathrm{C}$ over incubation period. Following retrieval, samples were filtered through GF/F filters on board. The filters were then placed in scintillation vials, and $0.5 \mathrm{ml}$ of $0.5 \mathrm{~N} \mathrm{HCl}$ was added to remove residual $\mathrm{H}^{14} \mathrm{CO}_{3}^{-}$. Radioactivity was counted in a liquid scintillation counter (Packard 2900) after the addition of $10 \mathrm{ml}$ scintillation cocktail (Ultima Gold, Packard) into the vials. The Chl- $a$ normalized production vs. light intensity (i.e., $\mathrm{P}^{\mathrm{B}}-\mathrm{E}$ ) curves were fitted with the Webb et al. (1974) model.

To avoid any diurnal effect of phytoplankton, water sample collected during the nighttime was stored in a $20 \mathrm{~L}$ carboy and incubated in a tank with running seawater. In the morning of the next day, samples were exposed to sunlight for $1-2$ hrs, then the $\mathrm{P}^{\mathrm{B}}-\mathrm{E}$ incubation experiment was performed.

Hourly sub-surface E was calculated by the light extinction coefficient and hourly surface incident PAR, the hourly $\mathrm{P}^{\mathrm{B}}$ profile was derived from the empirical $\mathrm{P}^{\mathrm{B}}$-E curve and sub-surface E. Hourly PP profile was estimated as the product of hourly $\mathrm{P}^{\mathrm{B}}$ profile and Chl- $a$ profile Gong et al. 2003). Finally, the daily PP for each station was derived by integrating (trapezoidal method) the hourly PP. One may refer Gong et al. [2003, their Eq. (1)] for the details of the integration equation. Note that it was assumed here that the sub-surface $\mathrm{E}$ and $\mathrm{Chl}-a$ profile remained unchanged although there were measured only once at each station.

\subsection{Bacterial Biomass, Production, and Growth Rate}

Bacterial abundance was estimated by Acridine Orange Direct Count method (Hobbie et al. 1977) with Epi-fluorescence microscope (Axioplan 2, Zeiss). Bacterial activity was measured by ${ }^{3} \mathrm{H}$-thymidine incorporation (TdR; Fuhrman and Azam 1982). Triplicates $1.7 \mathrm{ml}$ aliquots of water samples were incubated with ${ }^{3} \mathrm{H}$-[methyl]-thymidine (Sp. activity., 6.7 Ci mmole ${ }^{-1}$; final conc., $20 \mathrm{nM}$ ) in $2.0 \mathrm{ml}$ sterile plastic vials in the dark at in situ temperature. Formaldehyde was used (final concs., 1\%) to stop reaction. Bacteria cells in the killed samples were isolated via micro-centrifugation (Eppendorf Centrifuge $5810 \mathrm{R} ; 4^{\circ} \mathrm{C} ; 14000 \mathrm{rpm}$ ) method. Cell 
pellet were rinsed 3-times each with ice-cold 5\% trichloroacetic acid and ice-cold $80 \%$ ethyl alcohol sequentially. Scintillation cocktail (1.7 ml; Ultima Gold, Packard) was added for radioactivity determination in a Packard 2200 liquid scintillation counter. Bacterial biomass (BB) and production (BP) in C-unit were derived with a $\mathrm{TdR}$ and a carbon conversion factor of $1.8 \times 10^{18}$ cell mole $^{-1}$ and $2 \times 10^{-14} \mathrm{~g} \mathrm{C}$ cell $^{-1}$ respectively. Bacterial specific growth rates were calculated by dividing $\mathrm{BP}$ with $\mathrm{BB}$.

\subsection{Data Management and Statistical Analysis}

To compare the spatial (horizontal) variation of the bulk properties of measured variables for each cruise, depth-weighted mean stocks and rates at given station were obtained by dividing depth-integrated (trapezoidal method) values by the mixed-layer depth of that station. The mixedlayer depth was defined as the depth at which a change from the surface sigma- $t$ (density) of 0.125 has occurred (Levitus 1982). Capital letter "I" in front of the abbreviation of measurement denoted depth-integrated average. Statistical analysis was performed with the software of SPSS ${ }^{\circledR}$ V12.0.

\section{RESULTS}

\subsection{Vertical Profiles in the Summer}

For the comparison of the vertical structures in summer and winter, the data of transect 4 were used since it is the only transect that had been visited in these two seasons. Water column was temperature (T) stratified and ranged from $16.4-29.2^{\circ} \mathrm{C}$ (Fig. 2a). Salinity ( $\mathrm{S} ; 28.75$ - 34.58 psu; Fig. 2b) was low in the surface of the coastal stations as a result of freshwater discharge from the Pearl River. Concentrations of nitrate $\left(\mathrm{NO}_{3} ;\right.$ Fig. $\left.2 \mathrm{c}\right)$ were greatest $(14.9 \mu \mathrm{M})$ along the coast, decreasing with distance from the coast to a concentration < detection limit $(0.05 \mu \mathrm{M})$. Vertically, $\mathrm{NO}_{3}$ showed an increasing trend with depth. Chlorophyll- $a$ concentrations ranged $0.06-2.80 \mathrm{mg} \mathrm{Chl}-a \mathrm{~m}^{-3}$ (Fig. 2d) with higher concentrations at the coast and deep-water area. DOC varied $\sim 3$-fold with concentration ranged $54-169 \mu \mathrm{M}$ (Fig. 2e). In the inner- (stn. 40, 38, and 36) and outer-shelf (stn. 30, 28, and 26), DOC tended to decrease with depth. A reversed pattern (i.e., DOC increased with depth) was observed in the mid-shelf.

BB readings ranged from 5.5 to $\sim 29.8 \mathrm{mg} \mathrm{C} \mathrm{m}^{-3}$, and were lower at the surface water, then increased with depth at the inner-shelf. The pattern reversed at the mid- and outershelves (Fig. 2f). BP ranged from $<0.5$ to $\sim 15 \mathrm{mg} \mathrm{C} \mathrm{m}^{-3} \mathrm{~d}^{-1}$ ) with higher values recorded at the inner-shelf where $\mathrm{BP}$ increased with depth. Vertical patterns of BP in mid- and outershelves were opposite to that of the inner-shelf (Fig. $2 \mathrm{~g}$ ). B $\mu$ ranged from 0.04 to $\sim 0.56 \mathrm{~d}^{-1}$ (Fig. 2i) and followed similar patterns of BP as described above (Fig. 2f; Table 1).

Correlation analysis revealed that inorganic and or- ganic nutrients concentration and biological stocks and rates depth individual measurements of transect 4 (Table 1) were negatively correlated with $\mathrm{S}$ in the summer, indicating that these measurements were decreasing seaward. The relationship was indicative of allochthounous source coming in with coastal inputs. BB, BP, and $\mathrm{B} \mu$ were all positively correlated in horizontal and vertical space with DOC and Chl- $a$. DOC and Chl- $a$ were also correlated positively with each other.

\subsection{Vertical Profiles in the Winter}

The data of transect 4 was used for winter illustration. Homogenous distribution of $\mathrm{T}$ and $\mathrm{S}$ at respective station indicate recent physical mixing at respective near shore stations (inside mid-shelf). Outside the mid-shelf, $T$ readings were greater at the surface then decreased with depth. There was a negative correlation between $\mathrm{T}$ and $\mathrm{S}$ (Table 2). Note also that freshwater footprint in the coastal stations in the winter seemed to be more pronounced than that of the summer (Fig. 2b). The vertical pattern of $\mathrm{NO}_{3}(0.06-11.78 \mu \mathrm{M})$ (Fig. 3c) was opposite to those of $\mathrm{T}$ and $\mathrm{S}$ (Table 2), with higher readings in the coastal area and in the bottom-waters of the mid- and outer-shelves. Concentrations of $\mathrm{PO}_{4}(<\mathrm{de}-$ tection limit $-0.77 \mu \mathrm{M}$ ) followed the same trend with that of $\mathrm{NO}_{3}^{-}$(Table 2). Chl- $a$ concentrations (0.03 - $0.62 \mathrm{mg}$ Chl$a \mathrm{~m}^{-3}$; Fig. 3d) were generally high at the surface waters, decreasing with depth. Horizontally, higher Chl- $a$ readings appeared at the surface waters of the inner- and mid-shelves (Fig. 3d). DOC (73 - $190 \mu \mathrm{M}$; Fig. 3e) varied > 2-fold, showing negative vertical patterns with $\mathrm{T}$ and $\mathrm{S}$ (Table 2).

Vertically, values of BB (7.1 - $26.4 \mathrm{mg} \mathrm{C} \mathrm{m}^{-3}$; Fig. 3f) were higher at the surface and then decreased with depth. Horizontally, higher BB appeared at the transition zone (i.e., st. 34) of inner- and mid-shelves (Fig. 3f). Positive correlations were observed for BB vs. Chl- $a$ and BB vs. DOC (Table 3). On the other hand, BP (0.7 - 3.6 $\mathrm{mg} \mathrm{C} \mathrm{m}^{-3} \mathrm{~d}^{-1}$; Fig. $3 \mathrm{~g})$ and $\mathrm{B} \mu\left(0.03-0.28 \mathrm{~d}^{-1} ;\right.$ Fig. $\left.3 \mathrm{~h}\right)$ measurements covaried, and both rate parameters were opposite to $\mathrm{BB}$. This implied that the variation of $\mathrm{BP}$ was primarily controlled by variability of $\mathrm{B} \mu$ instead of $\mathrm{BB}$. Neither BP nor BB was significantly correlated to measures of any environmental variables (Table 2).

\subsection{Horizontal Patterns in the Summer}

Temperature (IT; $21.8-27.5^{\circ} \mathrm{C}$; Fig. 4a) showed strong gradient with warmer waters in the inner-shelf then decreased seaward. Salinity (IS; 31.27 - 34.48 psu; Fig. 4b) showed an opposite trend with that of IT (Table 3). Concentrations of nitrate $\left(\mathrm{INO}_{3} ;<0.05-7.1 \mu \mathrm{M}\right.$; Fig. 4c) were low in the inner-shelf, and then increased seaward. Higher $\mathrm{INO}_{3}$ values were recorded at the N-E and S-W corners of the sampling area. These two high anomalies resulted from high $\mathrm{NO}_{3}$ concentrations in the deep waters (Fig. 2c) after 
(a)
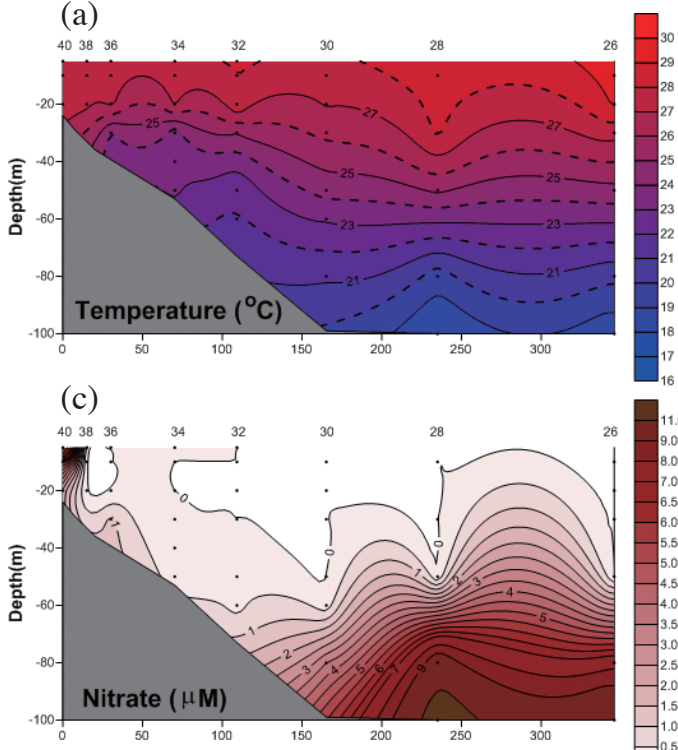

(e)

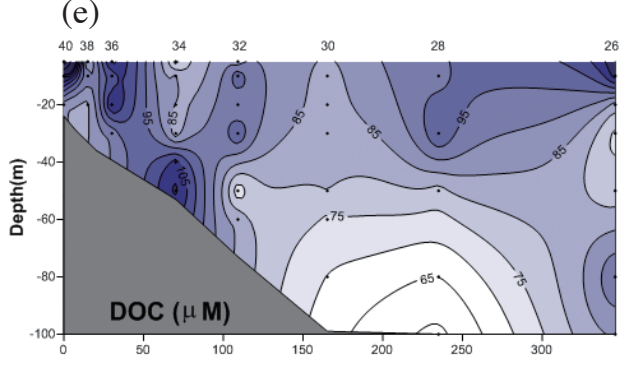

(g)

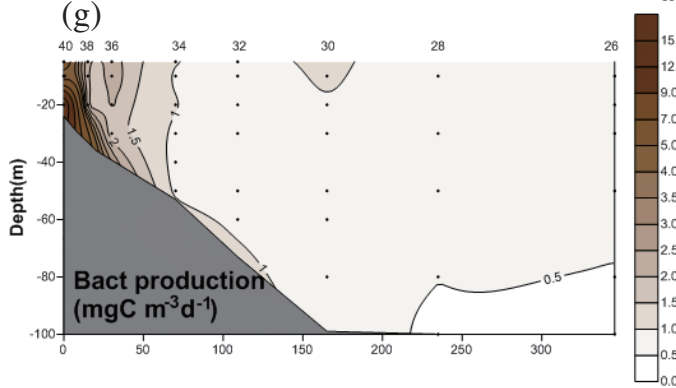

(b)

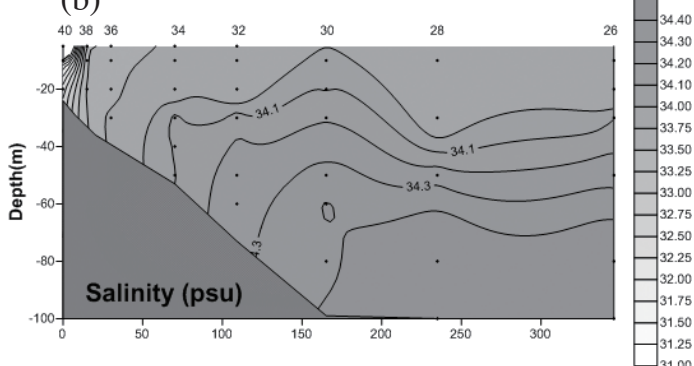

(d)

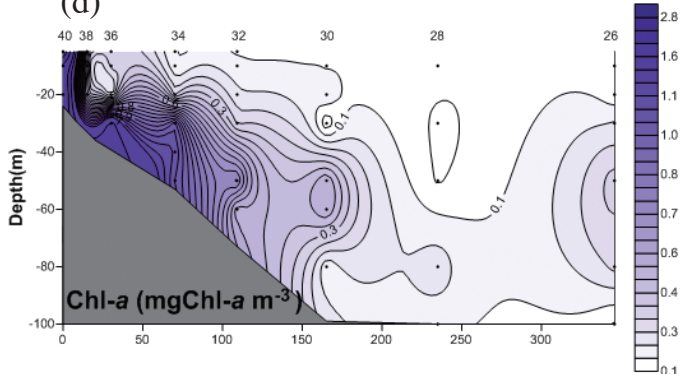

(f)

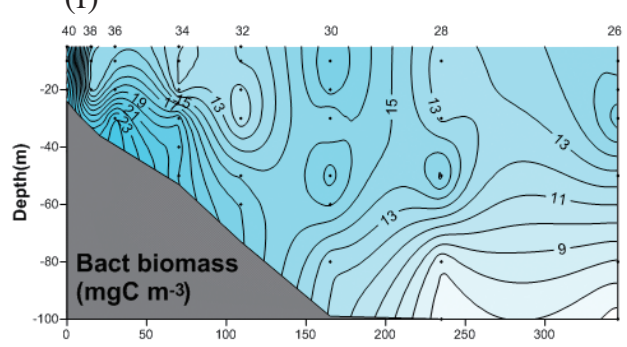

(h)

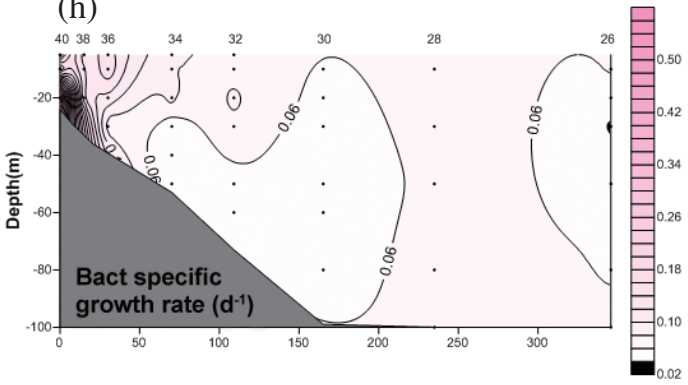

Fig. 2. Depth contours of measurements collected from transect 4 in June 2010. Numerical values in the upper and lower X-axes indicate station number and distance $(\mathrm{km})$ from coast, respectively.

Table 1. Correlation matrix for the individual depth measurements collected from Transect 4 of the June 2010 cruise. Symbols $* *$ and $*$ indicated significant at $\mathrm{p}$-value $<0.01$ and $<0.05$ levels, respectively. Abbreviation "na" means not analyzed. Symbol "-" denotes insignificant correlations.

\begin{tabular}{c|ccccccccc}
\hline Items & Unit & $\mathbf{T}\left({ }^{\circ} \mathbf{C}\right)$ & $\mathbf{S}$ & $\mathbf{N O}_{3}$ & $\mathbf{P O}_{4}$ & $\mathbf{C h l}-\boldsymbol{a}$ & $\mathbf{D O C}$ & $\mathbf{B B}$ & $\mathbf{B P}$ \\
\hline $\mathrm{S}$ & $\mathrm{psu}$ & - & & & & & & & \\
$\mathrm{NO}_{3}$ & $\mu \mathrm{M}$ & - & - & & & & & \\
$\mathrm{PO}_{4}$ & $\mu \mathrm{M}$ & $-0.87^{* *}$ & - & $0.73^{*}$ & & & & & \\
$\mathrm{Chl}-a$ & $\mathrm{mgChl}-a \mathrm{~m}^{-3}$ & - & $-0.96^{* *}$ & $0.85^{* *}$ & - & & & & \\
$\mathrm{DOC}$ & $\mu \mathrm{M}$ & $0.81^{*}$ & $-0.84^{* *}$ & - & - & $0.85^{* *}$ & & & \\
$\mathrm{BB}$ & $\mathrm{mgC} \mathrm{m^{-3 }}$ & $0.81^{*}$ & $-0.86^{* *}$ & - & - & $0.86^{* *}$ & $0.90^{* *}$ & & \\
$\mathrm{BP}$ & $\mathrm{mgC} \mathrm{m}^{-3} \mathrm{~d}^{-1}$ & $0.81^{*}$ & $-0.96^{* *}$ & - & - & $0.89^{* *}$ & $0.88^{* *}$ & na & \\
$\mathrm{B} \mu$ & $\mathrm{d}^{-1}$ & $0.74^{*}$ & $-0.93^{* *}$ & - & - & $0.84^{* *}$ & $0.81^{* *}$ & na & $0.88^{* *}$ \\
\hline
\end{tabular}

Note: T, $\mathrm{S}, \mathrm{DOC}, \mathrm{NO}_{3}, \mathrm{PO}_{4}, \mathrm{Chl}-\mathrm{a}, \mathrm{BB}, \mathrm{BP}$, and $\mathrm{B} \mu$ represented temperature, salinity, dissolved organic carbon, nitrate, phosphate, chlorophyll-a, bacterial biomass, bacterial production, and bacterial specific growth rate, respectively. IBB, IBP, and IB $\mu$ were $\log _{10}$ transformed. 
Table 2. The same as Table 1, but for the January 2011 cruise.

\begin{tabular}{cccccccccc}
\hline Items & Units & $\mathbf{T}\left({ }^{\circ} \mathbf{C}\right)$ & $\mathbf{S}$ & $\mathbf{N O}_{3}$ & $\mathbf{P O}_{4}{ }^{3}$ & $\mathbf{C h l}-\boldsymbol{a}$ & $\mathbf{D O C}$ & $\mathbf{B B}$ & $\mathbf{B P}$ \\
\hline $\mathrm{S}$ & $\mathrm{psu}$ & $0.91^{*}$ & - & & & & & & \\
$\mathrm{NO}_{3}$ & $\mu \mathrm{M}$ & $-0.73^{*}$ & $-0.77^{*}$ & & & & & & \\
$\mathrm{PO}_{4}{ }^{3}$ & $\mu \mathrm{M}$ & $-0.77^{*}$ & $-0.71^{*}$ & $0.96^{* *}$ & & & & & \\
$\mathrm{Chl}-a$ & $\mathrm{mgChl}-a \mathrm{~m}^{-3}$ & - & - & - & - & & & & \\
$\mathrm{DOC}$ & $\mu \mathrm{M}$ & $-0.64^{*}$ & $-0.73^{*}$ & - & - & - & & & \\
$\mathrm{BB}$ & $\mathrm{mgC} \mathrm{m} \mathrm{m}^{-3}$ & - & - & - & - & $0.85^{* *}$ & $0.76^{*}$ & & \\
$\mathrm{BP}$ & $\mathrm{mgC} \mathrm{m}^{-3} \mathrm{~d}^{-1}$ & - & - & - & - & - & - & na. & \\
$\mathrm{B} \mu$ & $\mathrm{d}^{-1}$ & - & - & - & - & - & - & na & $0.66^{*}$ \\
\hline
\end{tabular}

(a)

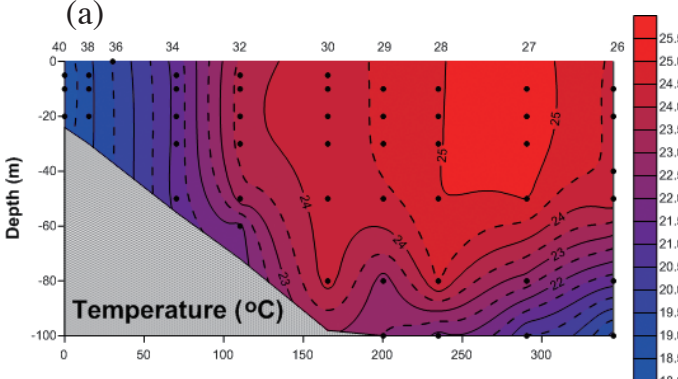

(c)

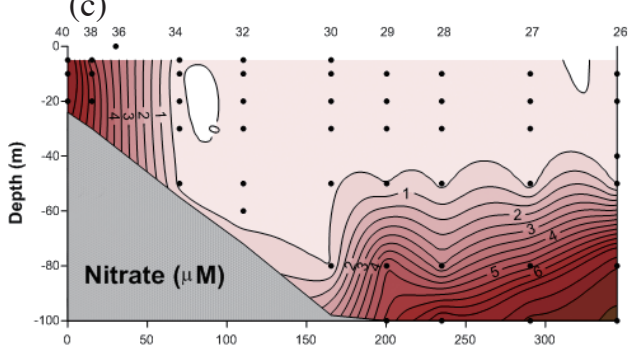

(e)

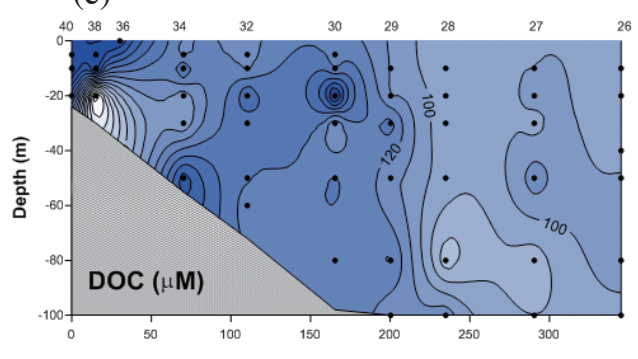

(g)

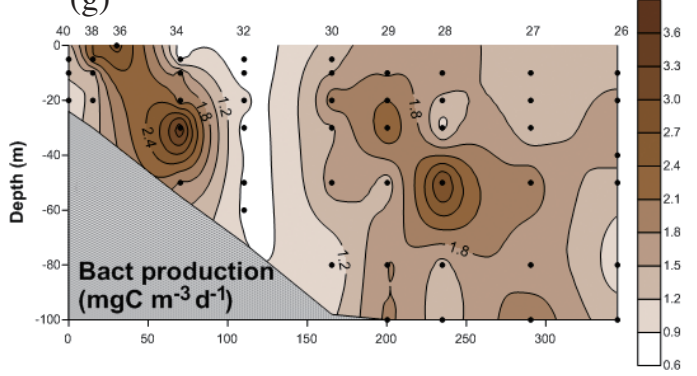

(b)

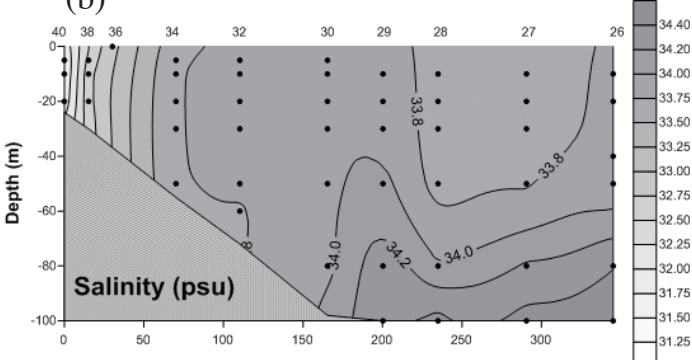

(d)

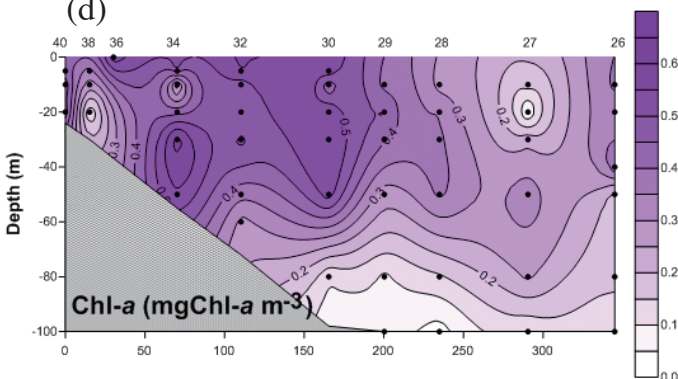

(f)

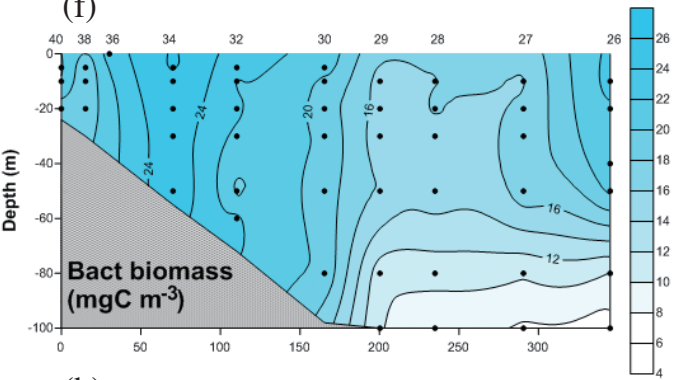

(h)

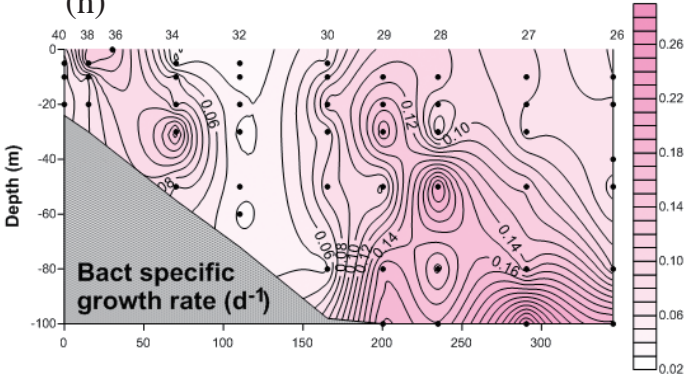

Fig. 3. The same as Fig. 2, but for the winter cruise conducted on transect 4 in January 2011. 
Table 3. Correlation matrix for the depth-integrated averages collected from the June 2010 cruise. Symbols ** and $*$ indicated significant at p-value $<0.01$ and $<0.05$, respectively. All data were depth-integrated averages. Abbreviation "na" means not analyzed. Symbol "-" denotes insignificant correlations.

\begin{tabular}{|c|c|c|c|c|c|c|c|c|c|c|}
\hline Items & Units & IT & IS & $\mathrm{INO}_{3}$ & $\mathrm{IPO}_{4}$ & IChl- $a$ & IDOC & IBB & IBP & $I B \mu$ \\
\hline IS & psu & $-0.68 * *$ & & & & & & & & \\
\hline $\mathrm{INO}_{3}$ & $\mu \mathrm{M}$ & $-0.44 * *$ & - & & & & & & & \\
\hline $\mathrm{IPO}_{4}$ & $\mu \mathrm{M}$ & $-0.85^{* *}$ & $0.40 *$ & $0.77 * *$ & & & & & & \\
\hline IChl- $a$ & $\mathrm{mgChl}-a \mathrm{~m}^{-3}$ & $0.56 * *$ & $-0.89 * *$ & - & $-0.43^{*}$ & & & & & \\
\hline IDOC & $\mu \mathrm{M}$ & $0.57 * *$ & $-0.49^{* *}$ & - & $-0.54 * *$ & $0.54 * *$ & & & & \\
\hline IBB & $\mathrm{mgC} \mathrm{m}{ }^{-3}$ & $0.57 * *$ & $-0.49^{* *}$ & $-0.43 *$ & $-0.63^{* *}$ & $0.61 * *$ & $0.59 * *$ & & & \\
\hline IBP & $\mathrm{mgC} \mathrm{m} \mathrm{m}^{-3} \mathrm{~d}^{-1}$ & $0.42 *$ & $-0.58 * *$ & - & - & $0.65^{* *}$ & $0.64 * *$ & na & & \\
\hline $\mathrm{IB} \mu$ & $\mathrm{d}^{-1}$ & - & $-0.55^{* *}$ & - & - & $0.60 *$ & $0.54 * *$ & na & $0.94 * *$ & \\
\hline IPP & $\mathrm{mgC} \mathrm{m} \mathrm{m}^{-3} \mathrm{~d}^{-1}$ & - & $-0.77 * *$ & & & $0.84 * *$ & - & $0.48^{* * *}$ & $0.64 * *$ & $0.65 * *$ \\
\hline
\end{tabular}

(a)

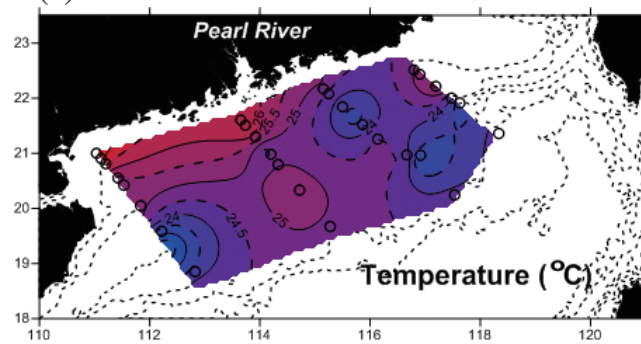

(c)

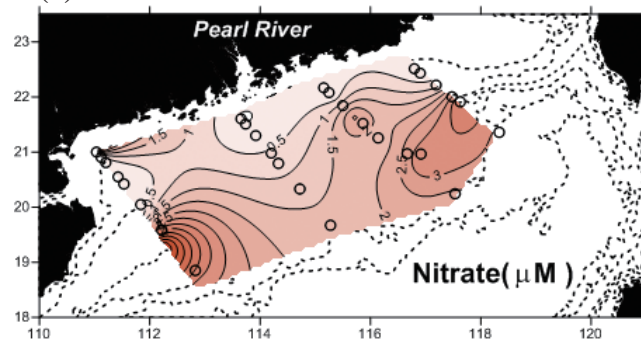

(e)

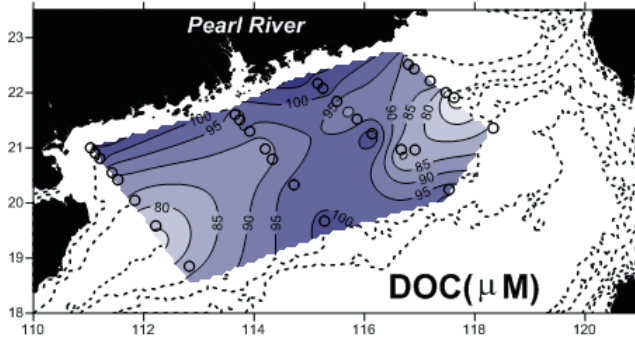

(g)

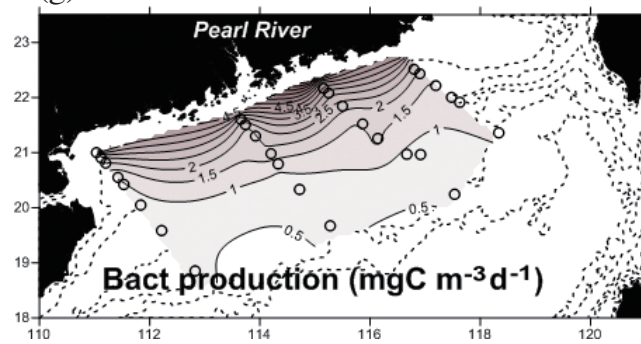

(b)

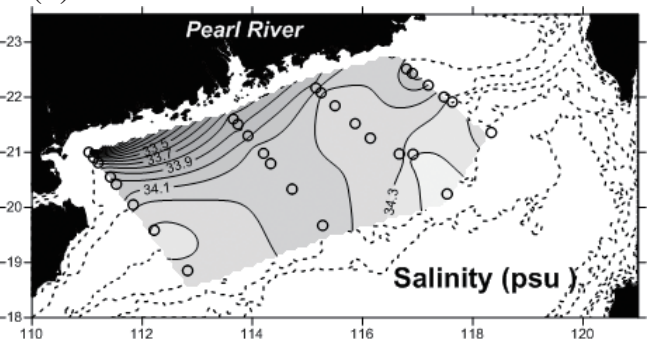

(d)

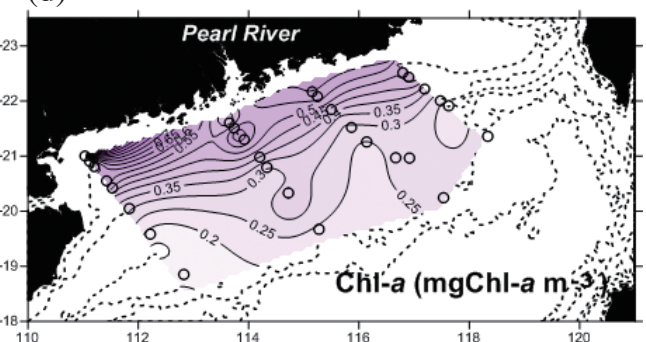

(f)

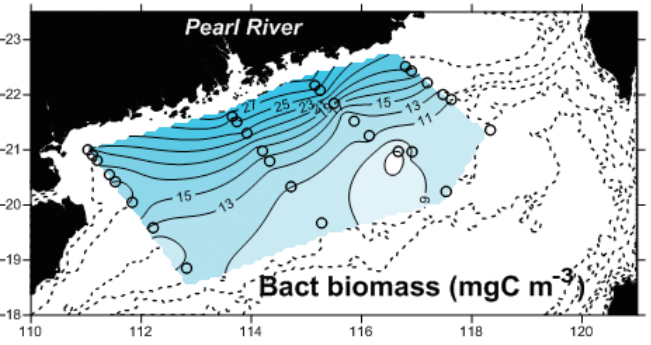

(h)

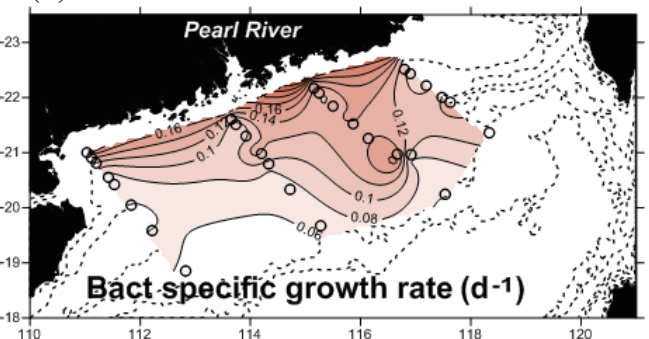

Fig. 4. Contour plots of depth-integrated averaged measurements collected from the June 2010 cruise in the South China Sea shelf. 
integration and averaging processes. Phosphate $\left(\mathrm{IPO}_{4}\right.$; $0.01-0.49 \mu \mathrm{M})$ showed a similar trend with that of $\mathrm{INO}_{3}$ (Table 3). Chlorophyll- $a$ concentrations (IChl- $a$; 0.14 $2.05 \mathrm{mg} \mathrm{Chl}-a \mathrm{~m}^{-3}$ ) varied $>10$ fold, with higher values (>0.5 mg Chl- $a \mathrm{~m}^{-3}$ ) observed in the inner-shelf (Fig. 4d). DOC concentrations (IDOC; Fig. 4e) ranged $65-116 \mu \mathrm{M}$. A positive correlation was observed between IDOC and IChl- $a$ (Table 3).

Bacterial biomass (IBB; Fig. 4f) varied $~ 3$-fold with a range of $8.9-30.6 \mathrm{mg} \mathrm{C} \mathrm{m}^{-3}$. Values of IBB were greatest in the coast, and then decreased seaward. Seaward decrease trend was also observed for bacterial production (IBP; 0.5 - $9.6 \mathrm{mg} \mathrm{C} \mathrm{m}^{-3} \mathrm{~d}^{-1}$; Fig. $4 \mathrm{~g}$ ) and bacterial specific growth rate (IB $\mu=$ IBP/IBB; $0.05-0.39 \mathrm{~d}^{-1}$; Fig. 4h). The spatial patterns of IBP and IB $\mu$ changed positively with IChl- $a$ and IDOC (Table 3). Depth integrated averages of primary production (figure not shown) varied $>50$-fold with a range of $0.4-20.6 \mathrm{mg} \mathrm{C} \mathrm{m}^{-3} \mathrm{~d}^{-1}$. Statistical analysis indicated that IBB (Fig. 5a), IBP (Fig. 5b), and IB $\mu$ (Fig. 5c) were positively correlated with IPP.

\subsection{Horizontal Patterns of Winter}

Figure 6 illustrated the spatial patterns of depthintegrated averages collected from transects 4 and PRS (Pearl River-to-SEATS) of the winter cruises. Both IT $\left(18.2-24.5^{\circ} \mathrm{C}\right.$; Fig. 6a) and IS (31.8 - $34.2 \mathrm{psu}$; figure not shown; Table 4) increased seaward then stabilized beyond the mid-shelf. Note that an IT of $4-5^{\circ} \mathrm{C}$ difference was observed between inner- and mid-shelves. Opposite to the trends of IT and IS (Table 4), $\mathrm{INO}_{3}^{-}(0.5-12.6 \mu \mathrm{M}$; figure not shown) and IChl- $a\left(0.20-0.85 \mathrm{mg}\right.$ Chl- $a \mathrm{~m}^{-3}$; Fig. 6b) decreased seaward (Table 4). IPP varied $>20$-fold ranging $0.27-6.23 \mathrm{mg} \mathrm{C} \mathrm{m}^{-3} \mathrm{~d}^{-1}$ (Fig. 6c), and did not correlate with any measured environmental factors.

Higher values of IBB (11.5 - $25.1 \mathrm{mg} \mathrm{C} \mathrm{m}^{-3}$; Fig. 6d) and IBP (0.8 to $2.8 \mathrm{mg} \mathrm{C} \mathrm{m}^{-3} \mathrm{~d}^{-1}$; Fig. 6e) were observed at the inner- and mid-shelves. Spatial pattern of IB $\mu(0.04$ $0.17 \mathrm{~d}^{-1}$ ) followed the trend of IBP (Table 4). As indicated by Table 4 , IBB, IBP and IB $\mu$ were correlated with IDOC. However, the relations of the former two to IDOC were positive, while that of the later $(\mathrm{IB} \mu)$ was negative. Further analysis revealed significant temperature responses of IBP (Fig. 7a) and IB $\mu$ (Fig. 7b) inside the mid-shelf areas within the IT range of $18-22^{\circ} \mathrm{C}$. The $\mathrm{Q}_{10}$ values for IBP and IB $\mu$ were $\sim 6.0$ and $\sim 4.0$, respectively. For stations (mainly in the outer-shelf) with IT $>22^{\circ} \mathrm{C}$, the trends of IBP (Fig. 7c) and IB $\mu$ (Fig. 7d) changed positively with IPP.

\subsection{Production Ratio of Bacteria vs. Phytoplankton (IBP/IPP Ratios)}

IBP/IPP ratios in summer and winter (pooled data) ranged $21-426$ and $27-368 \%$, with averages of $89 \pm 92$ and $131 \pm 88 \%$, respectively. In winter, the IBP/IPP ratios in the inner-shelf fluctuated between $60-180 \%$, increased seaward and reached a maximum at the mid-shelf with values $>300 \%$ (Figs. 6f and 8a). Beyond the mid-shelf, the ratios dropped dramatically with an average of $66 \pm 25 \%$. In summer, trend of the IBP/IPP ratios increased from inner- to mid-shelves and remained constantly low $(20-40 \%)$ at the oceanic end (Fig. 8a).

Multiple regression analysis indicated that the pooled (summer +2 winters) IBP/IPP ratios were determined by the variations of IPP negatively and IDOC positively (Table 5). However, the partial (standardized) regression coefficients (i.e., PRC $=$ slope/mean) of IPP and IDOC on the ratios were 0.91 and 0.11 respectively. This means the influence of IPP on the IBP/IPP ratios was 9-fold greater than that of IDOC with IPP explaining $46 \%$ of the variation of the ratios (Fig. 8b). Nevertheless, detailed analysis revealed that the best-fit equation varied with seasons and areas (Table 5). In summer, the impact of IDOC on the ratios almost equaled to that of IPP in the coastal zone (depth $<100 \mathrm{~m}$ ). In oceanic zone (depth $>100 \mathrm{~m}$ ), IPP was the only factor in explaining the variation of the ratios in both summer and winter. Along with IPP, temperature (Fig. 8c) affected the ratios positively in the coastal zone in winter. The relative importance of IT $(\mathrm{PRC}=0.98)$ for the ratios was about twice of that of IPP $(\mathrm{PRC}=0.51)$.

\section{DISCUSSIONS AND CONCLUSIONS}

$\mathrm{BB}$ is one of the two components of bacterial production (i.e., $\mathrm{BP}=\mathrm{BB} \times \mathrm{B} \mu$ ). It is generally accepted that bacterial biomass/abundance is primarily controlled by the topdown (bacterivory and viral lyses) processes, while $\mathrm{B} \mu$ is more or less independent of such processes (Ducklow and Shiah 1993; Shiah et al. 2003; Chen et al. 2016, and citations therein). We did not collect protozoan and virus data, which does not allow us to address top down effects in this study.

Similar to the ECS-shelf (Wong et al. 2000; Shiah et al. 2003), bacterial growth was most pronounced in the summer for areas inside the mid-shelf within the SCS-shelf. Like many other rivers in China, the discharge rate of the Pearl River reaches maxima in summer (June to September; http://www.pearlwater.gov.cn). It reasons then that external inputs such as inorganic nutrients and organic substrate (i.e., DOC) should also reach maximum at summer (Hung et al. 2003). High nutrient-loading together with warm water temperature appear to stimulate bacterial growth. It is puzzling that DOC was greater in winter when the river input was presumably lower. This potentially could mean the quality of DOC delivered via allochthounous or autochthonous processes during winter was of a quality that resisted removal by extant microbial assemblage.

The positive correlations of IPP (Figs. 5b - c), IChl$a$ and IDOC on IBP and IB $\mu$ (Table 4) indicated that the 

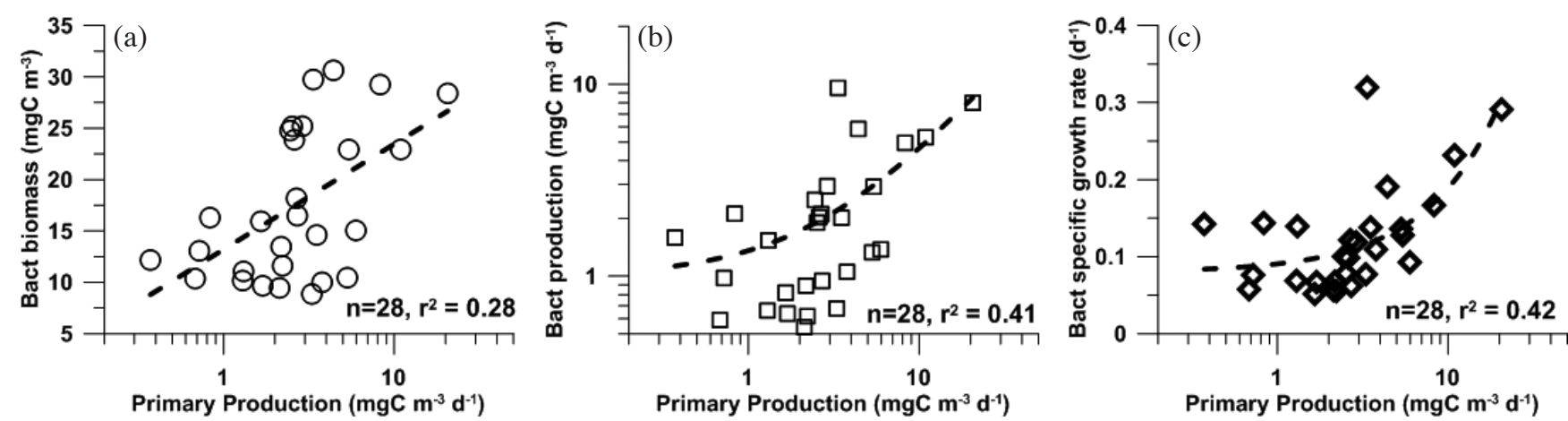

Fig. 5. Scatter plots showing the depth-integrated bacterial measurements vs. that of primary production of the June 2010 data. $\mathrm{r}^{2}$, coefficient of determination. Regression lines shown in all panels are significant at p-value $<0.05$.
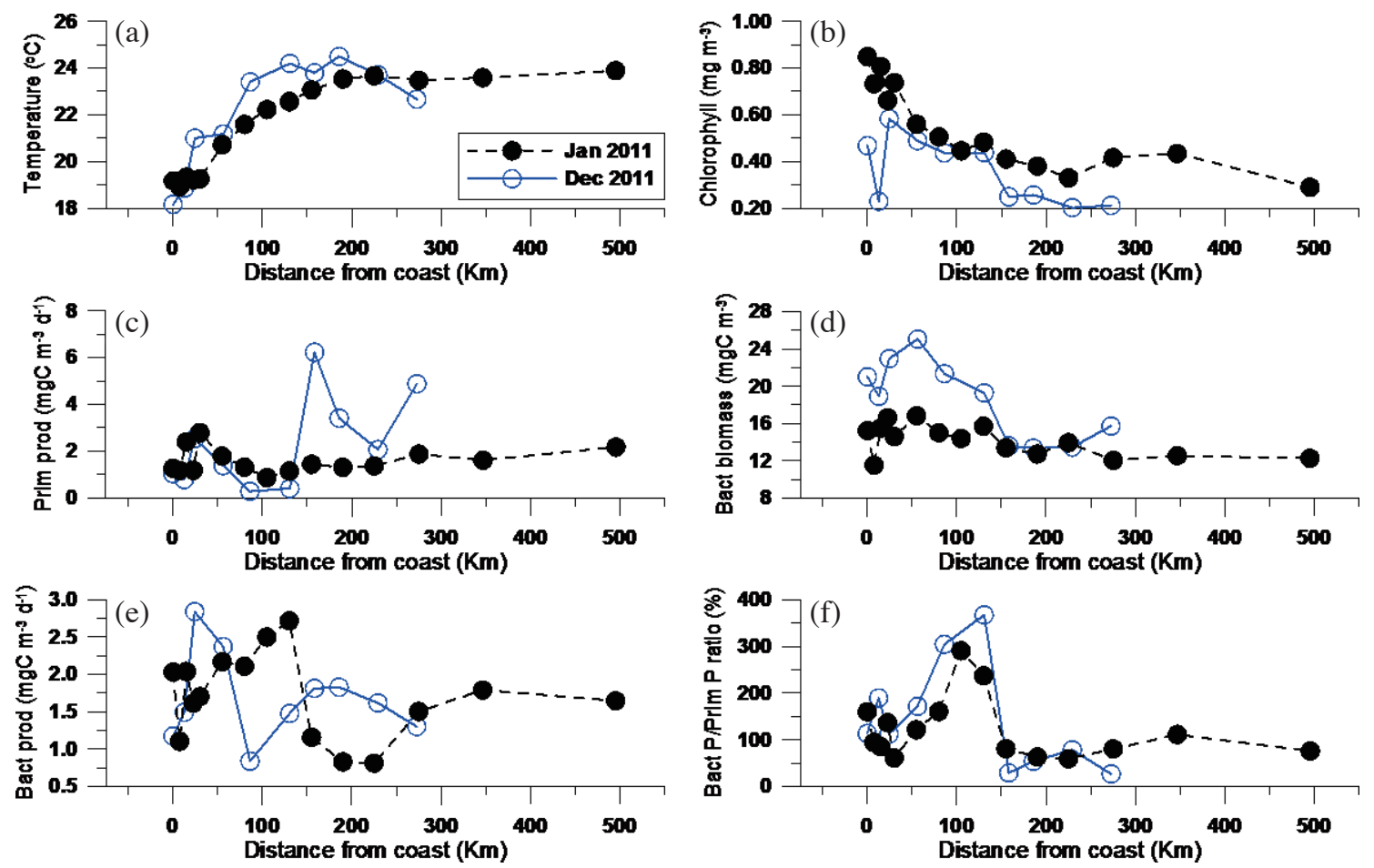

Fig. 6. Spatial distribution of the depth-integrated averages collected from the January and December 2011 cruises in the South China Sea shelf. (a) Temperature; (b) chlorophyll- $a$ concentration; (c) primary production; (d) bacterial biomass; (e) bacterial production; and (f) ratios of bacterial production to primary production.

Table 4. The same as Table 3, but for the depth-integrated averages pooled data collected from the January and December 2011 cruises.

\begin{tabular}{|c|c|c|c|c|c|c|c|c|c|c|}
\hline Items & Units & IT & IS & $\mathrm{INO}_{3}$ & $\mathrm{IPO}_{4}$ & IChl- $a$ & IDOC & IBB & IBP & IBu \\
\hline IS & psu & $0.93 * *$ & & & & & & & & \\
\hline $\mathrm{INO}_{3}$ & $\mu \mathrm{M}$ & $-0.89 * *$ & $-0.95^{* *}$ & & & & & & & \\
\hline $\mathrm{IPO}_{4}$ & $\mu \mathrm{M}$ & $-0.79 * *$ & $-0.89 * *$ & $0.90 * *$ & & & & & & \\
\hline IChl- $a$ & $\mathrm{mgChl}-a \mathrm{~m}^{-3}$ & $-0.67 * *$ & $-0.76^{* *}$ & $0.57 * *$ & $0.70 * *$ & & & & & \\
\hline IDOC & $\mu \mathrm{M}$ & - & - & - & - & - & & & & \\
\hline IBB & $\mathrm{mgC} \mathrm{m}{ }^{-3}$ & - & - & - & - & - & $0.56^{* *}$ & & & \\
\hline IBP & $\mathrm{mgC} \mathrm{m} \mathrm{m}^{-3} \mathrm{~d}^{-1}$ & - & - & - & - & - & $0.64 * *$ & na & & \\
\hline $\mathrm{IB} \mu$ & $\mathrm{d}^{-1}$ & - & - & - & - & - & $-0.50 * *$ & na & $0.83 * *$ & \\
\hline IPP & 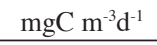 & - & - & - & - & - & - & - & - & - \\
\hline
\end{tabular}


(a)

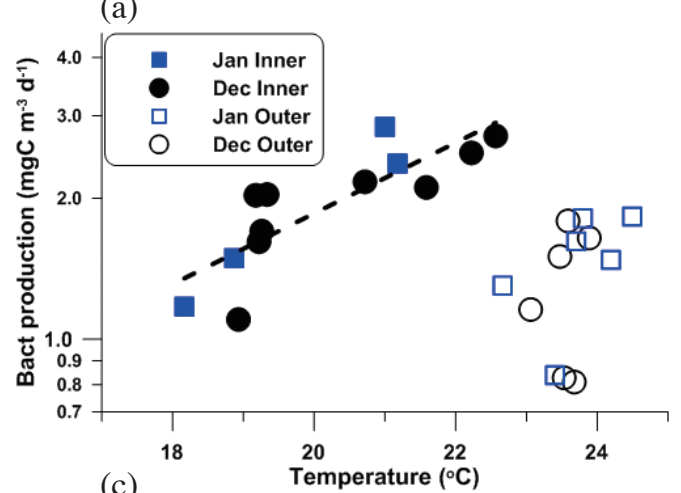

(c)

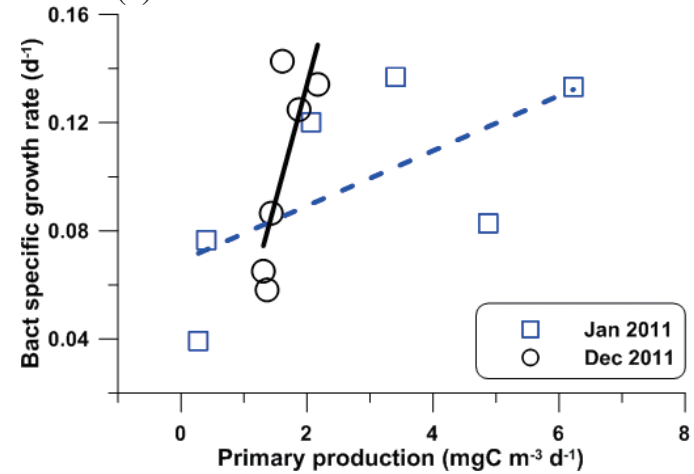

(b)
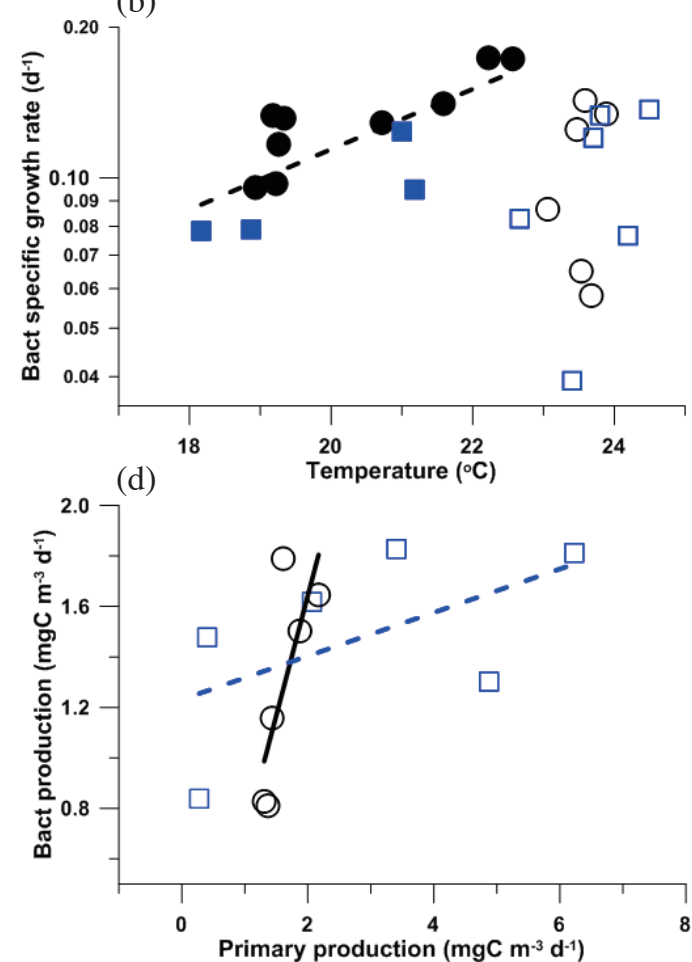

Fig. 7. Scatter plots of bacterial rate parameters vs. temperature (a) (b) and vs. primary production (c) (d) of the data collected from inner- and outer-shelves of the January and December 2011 cruises. Equations (significant at p-value $<0.05$ ) in panels (a) and (b) are $\mathrm{Ln}(\mathrm{BP})=-2.86+0.174$ $( \pm 0.035) \times \mathrm{T} ; \mathrm{n}=13, \mathrm{r}^{2}=0.69$, and $\mathrm{Ln}(\mathrm{B} \mu)=-4.94+0.138( \pm 0.036) \times \mathrm{T} ; \mathrm{n}=13, \mathrm{r}^{2}=0.47$ respectively. The lines shown in panels $(\mathrm{c})$ and $(\mathrm{d})$ were not significant at $\mathrm{p}$-value of 0.05 .
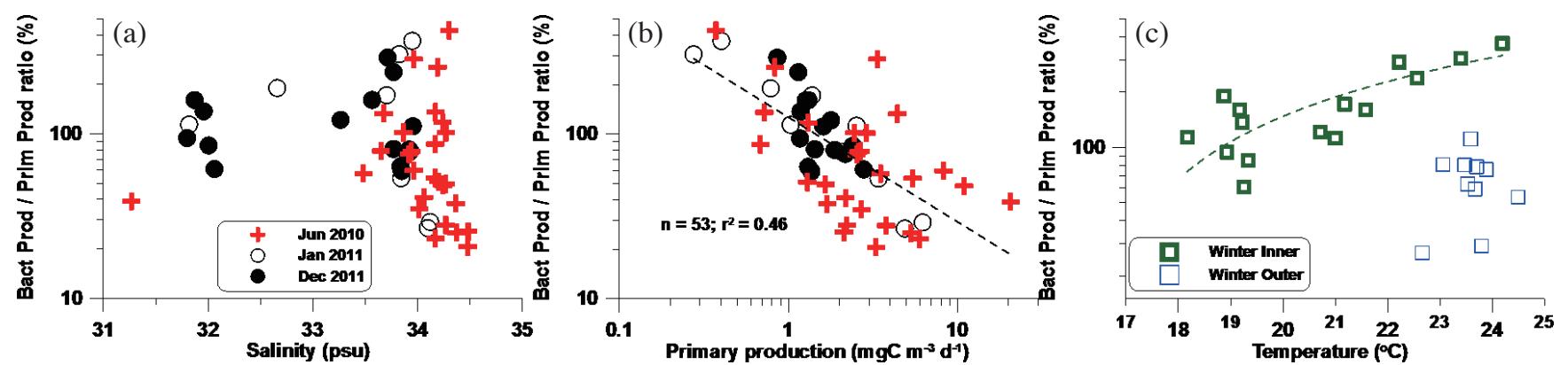

Fig. 8. Scatter plots of the ratios of bacterial production/primary production vs. salinity (a), primary production (b), and temperature (c). Regression lines shown in panels (b) and (c) are significant at p-value $<0.05$. Equation of the dash line in (c) is Ratios $=656+40.2( \pm 7.5) \times \mathrm{T}(\mathrm{n}=15$; $\left.\mathrm{r}^{2}=0.69\right)$

Table 5. The best-fit equations from multiple regression analysis for primary production (IPP), dissolved organic carbon (IDOC) and temperature (IT) on the production ratio of bacteria vs. phytoplankton (Y). All variables were natural-log transformed. $n$, sampling size. $r^{2}$, coefficient of determination. PRC, partial regression coefficient (= slope/mean). Listed best-fit equations are significant at $\mathrm{p}$-value $<0.05$.

\begin{tabular}{cclccc}
\hline Data set & Area & \multicolumn{1}{c}{ Best-fit equation@ } & $\mathbf{n}$ & $\mathbf{r}^{2}$ & PRC \\
\hline Pooled & Shelf & $\mathrm{Y}=+2.66-0.64( \pm 0.10) \times \mathrm{IPP}+0.49( \pm 0.31) \times \mathrm{IDOC}$ & 53 & 0.48 & $0.91: 0.11$ \\
\hline Summer & Coast & $\mathrm{Y}=-10.4-0.78( \pm 0.15) \times \mathrm{IPP}+3.46( \pm 1.43) \times \mathrm{IDOC}$ & 15 & 0.70 & $0.95: 0.77$ \\
& Ocean & $\mathrm{Y}=+4.30-0.80( \pm 0.14) \times \mathrm{IPP}$ & 13 & 0.74 & - \\
\hline \multirow{2}{*}{ Winter } & Coast & $\mathrm{Y}=-2.84-0.47( \pm 0.11) \times \mathrm{IPP}+2.63( \pm 0.80) \times \mathrm{IT}$ & 15 & 0.84 & $0.51: 0.98$ \\
& Ocean & $\mathrm{Y}=+4.67-0.69( \pm 0.17) \times \mathrm{IPP}$ & 10 & 0.68 & - \\
\hline
\end{tabular}

Note: No correlation between independent variables if more than one were used in equation. 
spatial (horizontal) pattern of bacterial growth in summer could be under substrate control (Cole et al. 1988; Shiah and Ducklow 1994a, b; Shiah et al. 2003, and citations therein). For vertical structure, we also observed positive correlations of Chl- $a$ and DOC on BP and B $\mu$ (Table 1), indicating bottom-up control on the vertical variations of $\mathrm{BP}$ and $\mathrm{B} \mu$ in summer. Note also that bacterial variables (i.e., BB, BP, and $\mathrm{B} \mu$ ) and $\mathrm{DOC}$ showed significant positive correlations with temperature, suggesting that the positive relationships between the above-mentioned bacterial variables and DOC might due to their co-variation with temperature, or temperature itself might play an additive role in affecting the vertical profile of these three bacterial variables. Overall, our summer data analysis indicated that summer bacterial growth in the northern SCS-shelf could be strongly affected by substrate supply, both horizontally and vertically. The results and conclusions stated above were similar to the summer cases that have been reported in the ECS-shelf by Shiah et al. (2003).

In winter, temperature responses of IBP and IB $\mu$ were only observed inside the mid-shelf area where temperatures were $<22^{\circ} \mathrm{C}$ (Figs. $7 \mathrm{a}-$ b). The calculated $\mathrm{Q}_{10}(\sim 4.0)$ value for IB $\mu$ in this study was higher than those reported in the ECS-shelf $\left(\mathrm{Q}_{10}=\sim 3.0\right.$; Shiah et al. 2000, 2003) and the temperature manipulation experiments $\left(\mathrm{Q}_{10}=2.72 \pm 0.26\right.$; Shiah and Ducklow 1994a), but within the range reported from the Chesapeake Bay $\left(\mathrm{Q}_{10}=1.5\right.$ to 5.47; Shiah and Ducklow 1994b, 1995). Note we only had 12 data points for this $Q_{10}$ calculation. Our high estimation (when compared with that of the ECS-shelf) might due to small sampling size.

Nevertheless, the " $20^{\circ} \mathrm{C}$ threshold" theory for bacterial rate parameters ( $\mathrm{BP}$ and $\mathrm{B} \mu$ ) observed in the ECS-shelf (Shiah et al. 2000, 2003) and the " $25^{\circ} \mathrm{C}$ growth optima" theory of the Chesapeake Bay (Shiah and Ducklow 1994a, b, 1995) seemed to hold for the SCS-shelf during the winter season. For warm waters stations $\left(\mathrm{IT}>22^{\circ} \mathrm{C}\right.$ ), bacterial growth rate seemed to be controlled by substrates generated by PP (Fig. 7d). This coincided with the results reported by the winter studies in the ECS-shelf (Shiah et al. 2003, and citations therein). Apple et al. (2006) used a $2^{\text {nd }}$ order polynomial to describe the relationship between temperature and BP in 4 estuarine sub-systems along the east shore of Chesapeake Bay (reported the temperature $3-30^{\circ} \mathrm{C}$ ). They estimated maximum at which BP no longer increased and began to decrease with temperature to be approximately $22^{\circ} \mathrm{C}$. Identical analysis of the composite literature dataset (Ducklow and Shiah 1993; Shiah and Ducklow 1994a, b; Shiah et al. 1999, 2000; Apple et al. 2006) revealed a similar maximum for $\mathrm{BP}$ of $\sim 21^{\circ} \mathrm{C}$.

The averaged IBP/IPP ratios in summer and winter (pooled data) were $89 \pm 92$ and $131 \pm 88 \%$, respectively. With a global averaged bacterial growth efficiency (BGE) of 20\% (Ducklow and Carlson 1992), bacterial carbon demand (i.e., BCD) to IPP ratios were 445 and $655 \%$ for the winter and summer respectively. Similar to the results of the ECS-shelf (Shiah et al. 2003), these results suggest that the majority of BCD in the northern SCS-shelf was supported by allochthonous organic matter, most likely came from river inputs and re-suspension (in winter) processes.

In winter, both bacterial production in the ECS- (Shiah et al. 2000, 2003) and SCS-shelves (Fig. 7a) responded significantly to the change of temperature inside the mid-shelf, where anthropogenic loadings of inorganic nutrients and DOC were high (Figs. 3c and e). Intuitively one may suspect that global warming might impact the $\mathrm{C}$-cycling of biogenic processes at temperate limited areas/seasons. As predicted by the regression analyses shown in Figs. 7a and 8c, as temperature rose, the values of IBP and the IBB/IPP ratios become higher, indicating that bacteria inside the mid-shelf area consume more organic carbon (Fig. 7a), and the system might be akin to a stronger source of $\mathrm{CO}_{2}$ (i.e., higher IBB/ IPP ratios) under a warming climate and increasing winter temperatures. However, this deduction is based on two assumptions; that the anthropogenic loadings through river input remain high in the future, and the empirical formulas of Figs. 7a and 8c calculated from short-term study are applicable to long-term scale (i.e., decades).

SCS is one of the few marine systems possessing significant internal solitary waves (i.e., IWs; Chang et al. 2006; Jan et al. 2008; Alford et al. 2010). According to Sharples et al. (2001), IWs profoundly impact nonlinear cross shelf transport processes and the enhancement of vertical mixing in shelf seas. From the results of several anchored diel studies, Lai et al. (2014) firstly suggested IWs could potentially affect bacteria production in the SCS-shelf. Chen et al. (2016) reported that the supply of 'new nutrient' via elevation IWs processes could enhance bacterial growth in in the shallow area (depth $<100 \mathrm{~m}$ ) of the SCS. Elevation IWs processes must have impacted our bacterial data, especially in the areas inside the mid-shelf. However, it is difficult to evaluate it effects since data were collected by snapshot sampling.

In conclusion, this study demonstrates that the controlling mechanisms of the tempo-spatial patterns of bacterial measurements in the northern SCS-shelf were very similar to what have been reported in the ECS-shelf. The "seasonal temperature-substrate switching control" and the "20 $-25^{\circ} \mathrm{C}$ threshold" theories on bacterial growth derived from the temperate ECS-shelf is still applicable to the tropical SCS-shelf. Calvo-Díaz et al. (2014) suggested that the relative strength of temperature and resource supply control on BP in the spring-summer transition seemed to be a general feature in temperate coastal waters. Very high ratios (> 400) of bacterial carbon demand to primary production observed in summer and winter suggest the system were net heterotrophic in the perspective of biogenic $\mathrm{C}$-cycling processes. Assuming the same allocthounous loading of organic and inorganic nutrients the positive temperature responses of bacterial production and the IBP/IPP ratios described 
here indicate that the coastal zone might become a stronger source of $\mathrm{CO}_{2}$ under a warming climate in winter.

Acknowledgements Funding for this research came from the NoSoCS project of MOST-Taiwan, and the AFOBi as well as the OA sustainability projects of Academia Sinica. Cruise assistance from the crews of Ocean Research I and III are deeply appreciated. We thank Mrs. Lisa Hsia for English editing. A dedication to late Drs. Kon-Kee Liu and Shih-Chieh Hsu.

\section{REFERENCES}

Alford, M. H., R.-C.Lien, H. Simmons, J.Klymak, S. Ramp, Y. J. Yang, D. Tang, and M.-H. Chang, 2010: Speed and evolution of nonlinear internal waves transiting the South China Sea. J. Phys. Oceanogr., 40, 1338-1355, doi: 10.1175/2010jpo4388.1. [Link]

Apple, J. K., P. A. del Giorgio, and W. M. Kemp, 2006: Temperature regulation of bacterial production, respiration, and growth efficiency in a temperate saltmarsh estuary. Aquat. Microb. Ecol., 43, 243-254, doi: 10.3354/ame043243. [Link]

Azam, F., 1998: Microbial control of oceanic carbon flux: The Plot thickens. Science, 280, 694-696, doi: 10.1126/ science. 280.5364.694. [Link]

Borges, A. V., 2005: Do we have enough pieces of the jigsaw to integrate $\mathrm{CO}_{2}$ fluxes in the coastal ocean? Estuaries, 28, 3-27, doi: 10.1007/bf02732750. [Link]

Borges, A. V., B. Delille, and M. Frankignoulle, 2005: Budgeting sinks and sources of $\mathrm{CO}_{2}$ in the coastal ocean: Diversity of ecosystems counts. Geophys. Res. Lett., 32, doi: 10.1029/2005GL023053. [Link]

Bott, T. L., 1975: Bacterial growth rates and temperature optima in a stream with a fluctuating thermal regime. Limnol. Oceanogr., 20, 191-197, doi: 10.4319/ lo.1975.20.2.0191. [Link]

Calvo-Díaz, A., L. Franco-Vidal, and X. A. G. Morán, 2014: Annual cycles of bacterioplankton biomass and production suggest a general switch between temperature and resource control in temperate coastal ecosystems. J. Plankton Res., 36, 859-865, doi: 10.1093/plankt/ fbu022. [Link]

Chang, M. H., R. C. Lien, T. Y. Tang, E. A. D'Asaro, and Y. J. Yang, 2006: Energy flux of nonlinear internal waves in northern South China Sea. Geophys. Res. Lett., 33, L03607, doi: 10.1029/2005GL025196. [Link]

Chen, T.-Y., J.-H. Tai, C.-Y. Ko, C. Hsieh, C.-C. Chen, N. Jiao, H.-B. Liu, and F.-K. Shiah, 2016: Nutrient pulses driven by internal solitary waves enhance heterotrophic bacterial growth in the South China Sea. Environ. Microbiol., 18, 4312-4323, doi: 10.1111/14622920.13273. [Link]

Cole, J., S. Findlay, and M. Pace, 1988: Bacterial produc- tion in fresh and saltwater ecosystems: A cross-system overview. Mar. Ecol. Prog. Ser., 43, 1-10, doi: 10.3354/meps043001. [Link]

Ducklow, H., G. Schultz, P. Raymond, J. Bauer, and F. K. Shiah, 1999: Bacterial dynamics in large and small estuaries. In: Bell, C. R., M. Brylinsky, and P. JohnsonGreen (Eds.), Microbial Ecology of Estuaries, Atlantic Canada Society for Microbial Ecology, Halifax, Canada, 105-111.

Ducklow, H. W. and C. A. Carlson, 1992: Oceanic bacterial production. In: Marshall K. C. (Ed.), Advances in Microbial Ecology, Springer, Boston, MA, 113-181, doi: 10.1007/978-1-4684-7609-5_3. [Link]

Ducklow, H. W. and F. K. Shiah, 1993: Bacterial production in estuaries. In: Ford, T. (Ed.), Aquatic Microbiology: An Ecological Approach, Blackwell Sciences Publication, Boston, 261-287.

Fuhrman, J. A. and F. Azam, 1982: Thymidine incorporation as a measure of heterotrophic bacterioplankton production in marine surface waters: Evaluation and field results. Mar. Biol., 66, 109-120, doi: 10.1007/ bf00397184. [Link]

Gong, G.-C., F.-K. Shiah, K.-K. Liu, Y.-H. Wen, and M.-H Liang, 2000: Spatial and temporal variation of chlorophyll $a$, primary productivity and chemical hydrography in the southern East China Sea. Cont. Shelf Res., 20, 411-436, doi: 10.1016/s0278-4343(99)00079-5. [Link]

Gong, G.-C., Y.-H. Wen, B.-W. Wang, and G.-J. Liu, 2003: Seasonal variation of chlorophyll $a$ concentration, primary production and environmental conditions in the subtropical East China Sea. Deep-Sea Res. Part II-Top. Stud. Oceanogr., 50, 1219-1236, doi: 10.1016/s09670645(03)00019-5. [Link]

Hedges, J. I., 1992: Global biogeochemical cycles: Progress and problems. Mar. Chem., 39, 67-93, doi: 10.1016/0304-4203(92)90096-S. [Link]

Hobbie, J. E., R. J. Daley, and S. Jasper, 1977: Use of nuclepore filters for counting bacteria by fluorescence microscopy. Appl. Environ. Microbiol., 33, 1225-1228.

Hoch, M. and D. Kirchman, 1993: Seasonal and inter-annual variability in bacterial production and biomass in a temperate estuary. Mar. Ecol.Prog. Ser., 98, 283-295, doi: 10.3354/meps098283. [Link]

Hung, J.-J., C.-H. Chen, G.-C. Gong, D.-D. Sheu, and F.K. Shiah, 2003: Distributions, stoichiometric patterns and cross-shelf exports of dissolved organic matter in the East China Sea. Deep-Sea Res. Part II-Top. Stud. Oceanogr., 50, 1127-1145, doi: 10.1016/s09670645(03)00014-6. [Link]

Jan, S., R. C. Lien, and C. H. Ting, 2008: Numerical study of baroclinic tides in Luzon Strait. J. Oceanogr., 64, 789-802, doi: 10.1007/s10872-008-0066-5. [Link]

Jickells, T. D., 1998: Nutrient biogeochemistry of the 
coastal zone. Science, 281, 217-222, doi: 10.1126/science.281.5374.217. [Link]

Lai, C.-C., Y.-W. Fu, H.-B. Liu, H.-Y. Kuo, K.-W. Wang, C.-H. Lin, J.-H. Tai, G. T. F. Wong, K.-Y. Lee, T.-Y. Chen, Y. Yamamoto, M.-F. Chow, Y. Kobayashi, and F.-K. Shiah, 2014: Distinct bacterial production-DOCprimary production relationships and implications for biogenic C-cycling in the South China Sea shelf. Biogeosciences, 11, 147-156, doi: 10.5194/bg-11-1472014. [Link]

Levitus, S., 1982: Climatological atlas of the world ocean. NOAA Professional Paper No. 13, 173 pp.

Lin, I.-I., J.-P. Chen, G. T. F. Wong, C.-W. Huang, and C.-C. Lien, 2007: Aerosol input to the South China Sea: Results from the MODerate resolution Imaging Spectro-radiometer, the quick scatterometer, and the measurements of pollution in the troposphere sensor. Deep-Sea Res. Part II-Top. Stud. Oceanogr., 54, 15891601, doi: 10.1016/j.dsr2.2007.05.013. [Link]

Lomas, M. W., P. M. Glibert, F. K. Shiah, and E. M. Smith, 2002: Microbial processes and temperature in Chesapeake Bay: Current relationships and potential impacts of regional warming. Global Change Biol., 8, 51-70, doi: 10.1046/j.1365-2486.2002.00454.x. [Link]

Mantoura, R. F. C., J. M. Martin, and R. Wollast, 1991: Ocean Margin Processes in Global Change, Wiley \& Sons, NY, 469 pp.

Parsons, T. R., Y. Maita, and C. M. Lalli, 1984: A Manual of Chemical \& Biological Methods for Seawater Analysis, Pergamon Press, 173 pp.

Ryther, J. H., 1969: Photosynthesis and fish production in the sea. Science, 166, 72-76, doi: 10.1126/science.166.3901.72. [Link]

Sharples, J., C. M. Moore, and E. R. Abraham, 2001: Internal tide dissipation, mixing, and vertical nitrate flux at the shelf edge of NE New Zealand. J. Geophys. Res., 106, 14069-14081, doi: 10.1029/2000jc000604. [Link]

Shiah, F. K. and H. W. Ducklow, 1994a: Temperature and substrate regulation of bacterial abundance, production and specific growth rate in Chesapeake Bay, USA. Mar. Ecol. Prog. Ser., 103, 297-308.

Shiah, F. K. and H. W. Ducklow, 1994b: Temperature regulation of heterotrophic bacterioplankton abundance, production, and specific growth rate in Chesapeake Bay. Limnol. Oceanogr., 39, 1243-1258, doi: 10.4319/ 1o.1994.39.6.1243. [Link]

Shiah, F. K. and H. W. Ducklow, 1995: Multiscale variability in bacterioplankton abundance, production, and specific growth rate in a temperate salt-marsh tidal creek. Limnol. Oceanogr., 40, 55-66, doi: 10.4319/ 10.1995.40.1.0055. [Link]

Shiah, F. K., G. C. Gong, and K. K. Liu, 1995: A preliminary survey on primary productivity measured by the $14 \mathrm{C}$ assimilation method in the KEEP area. Acta Oceanogr. Taiwan., 34, 1-16.

Shiah, F. K., K. K. Liu, and G. C. Gong, 1999: Temperature versus substrate limitation of heterotrophic bacterioplankton production across trophic and temperature gradients in the East China Sea. Aquat. Microb. Ecol., 17, 247-254, doi: 10.3354/ame017247. [Link]

Shiah, F. K., G. C. Gong, T. Y. Chen, and C. C. Chen, 2000: Temperature dependence of bacterial specific growth rates on the continental shelf of the East China Sea and its potential application in estimating bacterial production. Aquat. Microb. Ecol., 22, 155-162, doi: 10.3354/ ame022155. [Link]

Shiah, F. K., G.-C. Gong, and C.-C. Chen, 2003: Seasonal and spatial variation of bacterial production in the continental shelf of the East China Sea: Possible controlling mechanisms and potential roles in carbon cycling. Deep-Sea Res. Part II-Top. Stud. Oceanogr., 50, 12951309, doi: 10.1016/s0967-0645(03)00024-9. [Link]

Webb, W. L., M. Newton, and D. Starr, 1974: Carbon dioxide exchange of Alnus rubra: A mathematical model. Oecologia, 17, 281-291, doi: 10.1007/BF00345747. [Link]

Wong, G. T. F., S.-Y. Chao, Y.-H. Li, and F.-K. Shiah, 2000: The Kuroshio edge exchange processes (KEEP) study - an introduction to hypotheses and highlights. Cont. Shelf Res., 20, 335-347, doi: 10.1016/s02784343(99)00075-8. [Link]

Wong, G. T. F., X. Pan, K.-Y. Li, F.-K. Shiah, T.-Y. Ho, and $X$. Guo, 2015: Hydrography and nutrient dynamics in the Northern South China Sea Shelf-sea (NoSoCS). Deep-Sea Res. Part II-Top. Stud. Oceanogr., 117, 2340, doi: 10.1016/j.dsr2.2015.02.023. [Link] 